\title{
CRAYFISH PREDATION ON TADPOLES : A COMPARISON BETWEEN A NATIVE (AUSTROPOTAMOBIUS PALLIPES) AND AN ALIEN SPECIES (PROCAMBARUS CLARKII).
}

\author{
F. GHERARDI, B. RENAI, C. CORTI \\ Department of Animal Biology and Genetics 'Leo Pardi', University of Florence, Via \\ Romana 17, 50125 Florence, Italy.
}

\begin{abstract}
In the laboratory, the motivation and/or ability to prey on anuran larvae (Bufo bufo, Rana kl. esculenta and $R$. italica) were compared between a native European (Austropotamobius pallipes) and an alien North American crayfish species (Procambarus clarkil). Both were skilled predators of tadpoles, adopting a sit-and-wait strategy. However, because P. clarkii displayed lower latency times in the presence of one of the three amphibians (Rana kl. esculenta) here tested, the hypothesis is raised that invasive crayfish are more opportunistic predators and possibly faster in switching to different prey than those species they are displacing. From a conservation perspective, these preliminary results further emphasise the importance of studies centred on the invasion-displacement dichotomy.
\end{abstract}

Key-words : alien species, crayfish, predation, amphibian tadpoles, biodiversity conservation, Austropotamobius pallipes, Procambarus clarkii.

\section{PRÉDATION DE TÊTARDS PAR LES ÉCREVISSES : COMPARAISON ENTRE UNE ESPĖCE AUTOCHTONE (AUSTROPOTAMOBIUS PALLIPES) ET UNE ESPÈCE ÉTRANGĖRE (PROCAMBARUS CLARKII).}

\section{RÉSUMÉ}

Les auteurs ont testé en laboratoire la motivation et/ou la capacité de prédation sur les larves d'Anoures (Bufo bufo, Rana kl. esculenta et $R$. italica) entre une espèce native (Austropotamobius pallipes) et une espèce introduite (Procambarus clarkii) d'écrevisse. Les deux espèces se sont montrées comme d'habiles prédateurs de têtards, en adaptant une tactique d'immobilité et d'attente. Cependant on peut avancer l'hypothèse, en raison du fait que $P$. clarkii montre une période de latence plus courte en présence d'une des trois espèces d'amphibiens (Rana kl. esculenta) testées ici, que l'écrevisse introduite est un prédateur plus opportuniste et probablement plus rapide que l'espèce qu'elle est en train de remplacer. Du point de vue de la conservation, ces résultats préliminaires font ressortir l'importance des études sur la dichotomie invasion-déplacement.

Mots-clés : espèce étrangère, écrevisse, prédation, têtards d'amphibiens, conservation de la biodiversité, Austropotamobius pallipes, Procambarus clarkii. 


\section{INTRODUCTION}

There are more than 60 amphibian species in Europe (GASC et al., 1997), several of which are declining and more than half are considered as threatened (CORBETT, 1989). It is well documented that mortality during the aquatic stage regulates both the extent and the diffusion of the amphibian populations (SMITH, 1983). In North America, their decline has been related also to the introduction of alien aquatic predators (FISHER and SHAFFER, 1996 ; GAMRADT and KATS, 1996).

Although mostly based on anecdotal observations, several authors (CORBETT, 1989 ; CEDHAGEN and NILSON, 1991 ; FOG et al., 1997) reported that alien crayfish threaten European amphibian species. A direct effect of introduced crayfish on amphibians has been shown in detail in Procambarus clarkii inhabiting some Californian streams (DIAMOND, 1996). Predation on eggs, larvae and adults of the newts Taricha torosa was seen as one factor leading to the disappearance of the species, which does not have mechanisms of defence against the new predator (DIAMOND, 1996). Crayfish are resistant to tetrodotoxin poison in newt adults and eggs, are able to open the egg mass' protective gelatin, and are not recognised as predators by the larval newts, which fail to identify chemical cues from the crayfish (DIAMOND, 1996). An example of the indirect impact on amphibian populations by alien crayfish was provided by AXELSSON et al. (1997), who demonstrated that an increase of the predation rate upon the tadpoles of the European green tree frog, Hyla arborea, was a consequence of the reduction in the habitat complexity due to the consumption of macrophytes by the alien North American crayfish, Pacifastacus leniusculus.

The potential for a crayfish species to be invasive depends on a number of features, and is related to its ability to withstand environmental extremes, and to show polytrophism, early maturity, rapid growth rate, high fecundity, disease resistance (LINDQVIST and HUNER, 1999), plasticity in the biological cycle (GHERARDI et al., 1999), and responsiveness to a wide array of danger signals (HAZLETT, 2000 ; GHERARDI et al., 2002). Active dispersal capabilities can increase the extent of habitat occupation (GHERARDI and BARBARESI, 2000).

The object of this preliminary study was to compare the predatory pressure displayed by one native European and one alien North American crayfish species on the larvae of amphibian anurans from three different species. The assumption was that a faster readiness to react towards potential prey, even if relatively new for them, allows alien species to out-compete native crayfish; this might threaten the biodiversity of freshwater communities.

\section{MATERIAL AND METHODS}

\section{The study animals}

\section{Crayfish}

The white-clawed crayfish, Austropotamobius pallipes, is native to Western Europe and occupies a wide geographical range in Europe from Dalmatia and the former Yugoslavia in the east, through Italy, France, Switzerland, northern and central Spain and northern Portugal to the British Isles (LAURENT, 1988 ; HOLDICH, 1996). Efforts have been undertaken to protect this species, " whose taking in the wild and exploitation may be subject to management measures " (Council directive 92/43/ECC of 21 May 1992). Notwithstanding, the introduction of foreign species spreading the crayfish plague and other factors such as pollution (including acidification), over-fishing, waterworks, floods and drought are still changing the natural situation (LAURENT, 1988; HOGGER, 1988 ; 
WESTMAN et al., 1990 ; HOLDICH and REEVE, 1991 ; FOSTER and SLATER, 1995 ; HOLDICH et al., 1995 ; HOLDICH, 1996).

The red swamp crayfish, Procambarus clarkii, has become one of the most invasive freshwater species (HUNER, 1977 ; HUNER and AVAULT, 1979). Since it was taken from its native north-eastern Mexico to south-central USA for aquaculture ventures (HUNER, 1988a), it has spread around the world except Australia (HUNER, 1988b, 1995 ; GHERARDI and HOLDICH, 1999). This crayfish species is well established in northern and central Italy with breeding populations. It is undergoing a great expansion in some sectors of the Po and Reno River drainage basins, in Tuscany, Umbria, the Marches, Latium and Abruzzo (GHERARDI et al., 1999). A possibility exists that the two species will enter in contact in the near future.

\section{Amphibia anurans}

The common toad, Bufo bufo, is terrestrial and moves to water during the breeding season. It is the most ubiquitous amphibian of Europe. Eggs and feeding larvae are to be found in still waters. Eggs are distributed in a gelatinous string (LANZA, 1983 ; DUELLMAN and TRUEB, 1994). Rana kl. esculenta is a green frog, typical inhabitant of lentic waters. Eggs are deposited in clutches in shallow water (LANZA, 1983). Rana italica mostly lives in lotic waters. This brown frog deposits clutches of eggs which are anchored at submerged stones (LANZA, 1983).

\section{The experimental protocol}

Experiments were carried out during spring and summer, 1999. Individuals of A. pallipes were collected by hand in Fosso di Farfereta, a third order stream $40 \mathrm{~km}$ from Florence at an altitude of $450 \mathrm{~m}$ above sea level. Procambarus clarkii was collected using cylindrical baited traps ( $80 \mathrm{~cm}$ long, $28 \mathrm{~cm}$ in diameter and $4 \mathrm{~mm}$ in mesh size) in Padule di Fucecchio, a freshwater swamp $60 \mathrm{~km}$ from Florence at an altitude of $15 \mathrm{~m}$ above sea level.

For at least one week before testing, crayfish were kept in a room where the natural L/D cycle and ambient temperature were maintained. Specimens were reared in mass in plastic tanks where the water was filtered by a pump and fed on Tetramin fish flakes and earthworms once per day. For "satiated" individuals the authors mean those crayfish which were fed two times per day for three days before the experiment, while the other crayfish were starved for three days. Tadpoles were collected in freshwater systems in the neighbourhood of Florence, maintained in the laboratory in communal tanks isolated per species and fed with boiled salad. Those tadpoles that were used dead in the experiments were killed in a freezer at $-30^{\circ} \mathrm{C}$ where death occurred in a few seconds.

Randomly sized and sexed adult specimens of both crayfish species were used. Individuals were tested in circular aquarium (diameter $30 \mathrm{~cm}$ ) containing $5 \mathrm{I}$ of water. The latency time before the capture of the prey (when it occurred) was recorded. If the tadpoles were not consumed in the period of observation, aquaria were checked after about $12 \mathrm{~h}$. Five experiments were carried out, with 20 replicates per crayfish species per test ; each specimen was used only once and kept in the laboratory for at least two weeks after the experiment.

The experiments were as follows :

Experiment 1: One live tadpole of $B$. bufo was offered to both crayfish species, comparing between either starved or satiated crayfish. 
Experiment 2 : Either one dead or one live tadpole of $B$. bufo was offered to starved crayfish of both species.

Experiment 3: Either one or three live tadpole/es of $B$. bufo was/were offered to starved crayfish of both species.

Experiment 4 : One live tadpole of $R$. kl. esculenta was offered to either starved or satiated crayfish of both species.

Experiment 5 : One live tadpole of either $B$. bufo or $R$. kl. esculenta or $R$. italica were offered to starved crayfish of both species.

\section{Statistical analyses}

The comparison between species and among treatments was done using the twoway ANOVA (ZAR, 1984). Figures give mean values + standard error. The level of significance at which the null hypothesis was rejected is $\alpha=0.05$.

\section{RESULTS}

\section{Experiment 1}

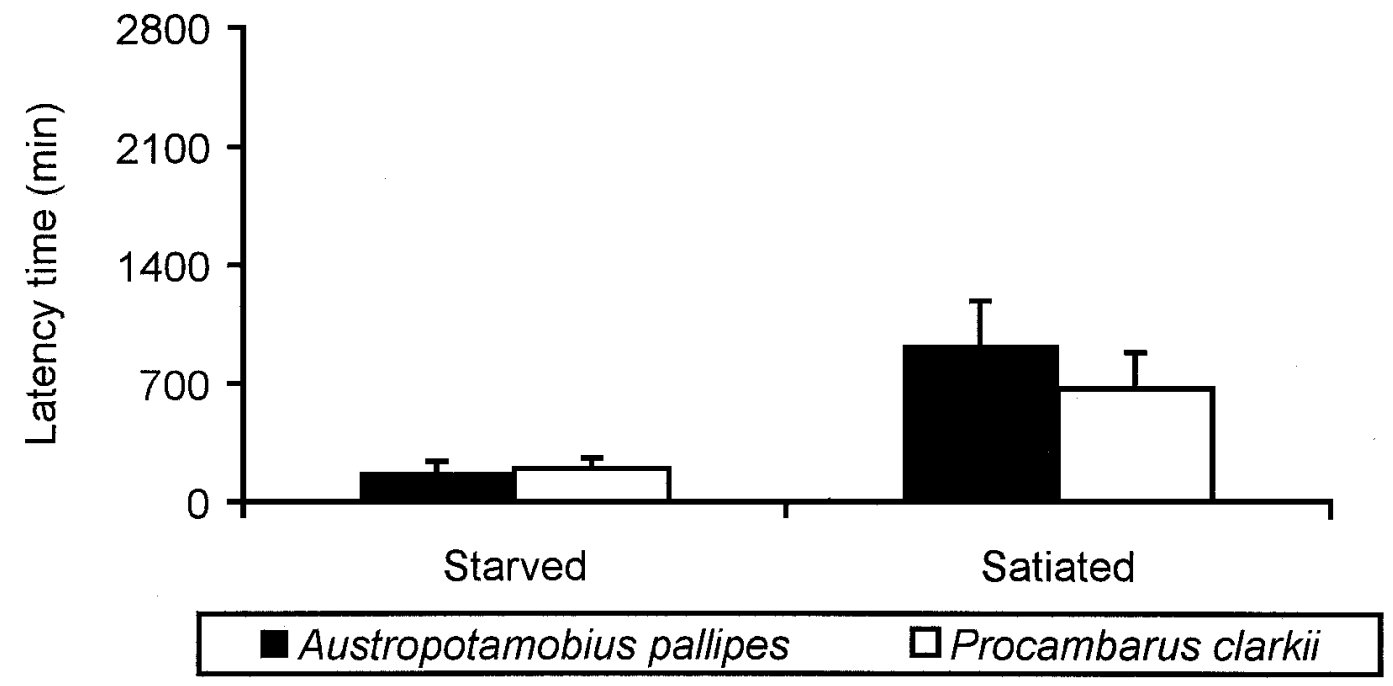

\section{Figure 1}

Time spent in capturing one live Bufo bufo tadpole by either starved or satiated crayfish.

\section{Figure 1}

Temps mis pour capturer un têtard vivant de Bufo bufo par une écrevisse soit privée de nourriture, soit rassasiée.

In the presence of one live $B$. bufo tadpole, the two species did not differ in the time spent in capturing prey $(F=0.45, d f=1 \& 76, P>0.05)$. As expected, starved crayfish caught tadpoles faster than satiated ones $(F=12.37$, df $=1 \& 76, P<0.01)$. 


\section{Experiment 2}

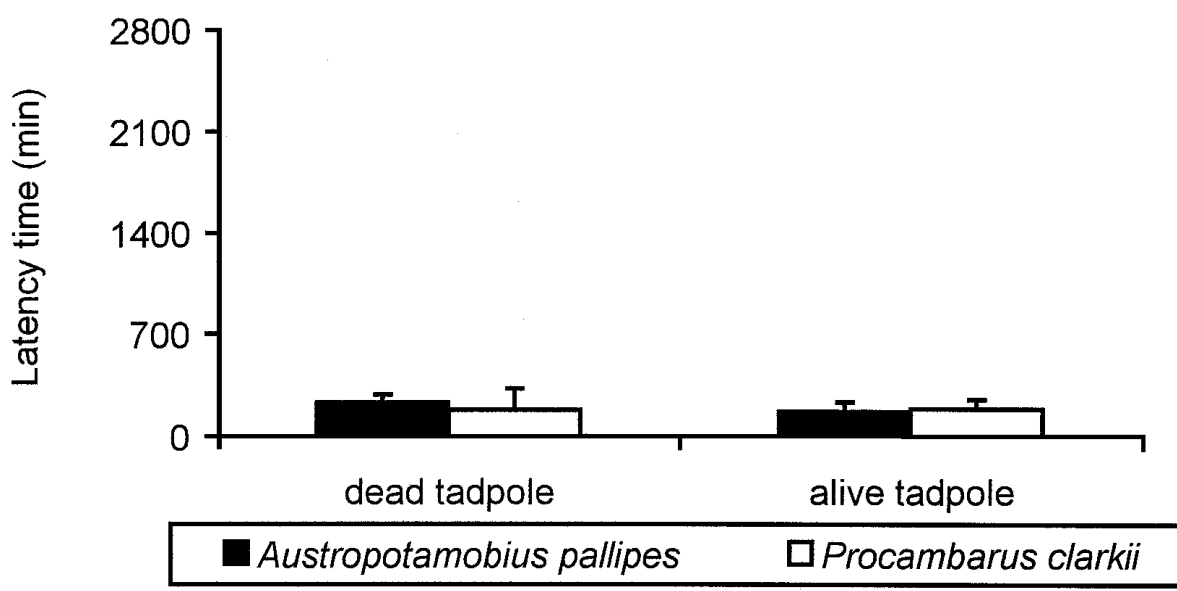

Figure 2

Time spent in capturing either one dead or one live Bufo bufo tadpole.

\section{Figure 2}

Temps mis pour capturer un têtard de Bufo bufo soit mort, soit vivant.

The two starved crayfish required a similar time in preying on either one dead or one live $B$. bufo tadpole $(F=0.07, \mathrm{df}=1 \& 76, P>0.05)$, without any difference between species $(F=0.03, d f=1 \& 76, P>0.05)$.

\section{Experiment 3}

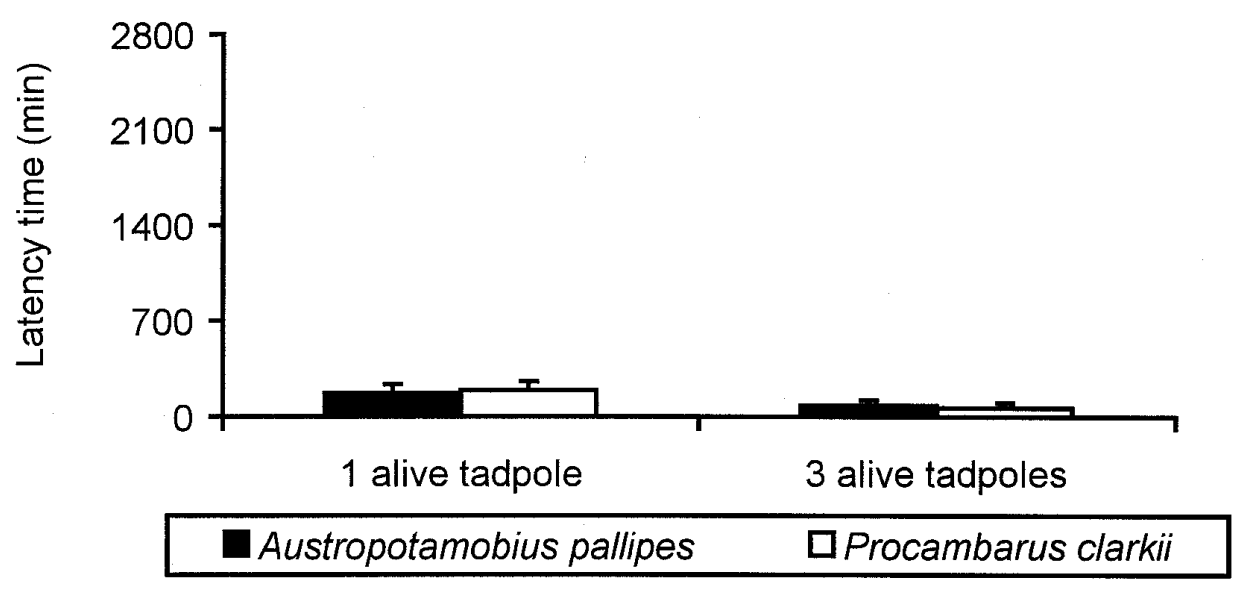

\section{Figure 3}

Time spent in capturing either one or three live Bufo bufo tadpoles.

\section{Figure 3}

Temps mis pour capturer soit un, soit trois têtards vivants de Bufo bufo.

In starved individuals, the latency time significantly decreased with the number of the offered, live prey $(F=4.02, d f=1 \& 76, P<0.05)$, without any difference between crayfish species $(F=0.01, \mathrm{df}=1 \& 76, \mathrm{P}>0.05)$. 
Experiment 4

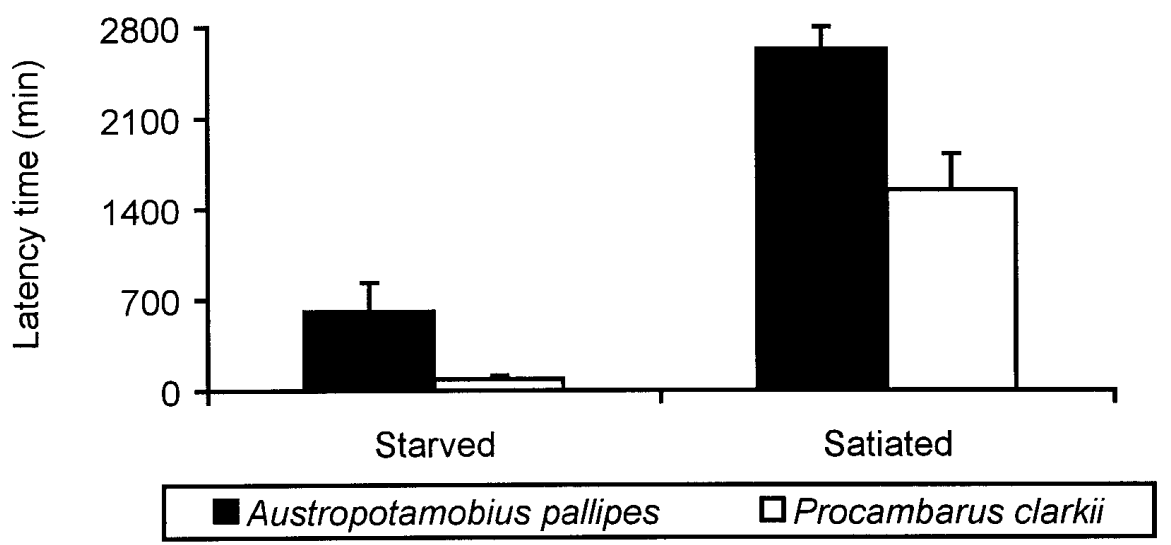

Figure 4

Time spent in capturing one live Rana kl. esculenta tadpole by either starved or satiated crayfish.

\section{Figure 4}

Temps mis pour capturer un têtard de Rana kl. esculenta par une écrevisse soit privée de nourriture, soit rassasiée.

Procambarus clarkii captured live $R$. kl. esculenta tadpoles faster than $A$. pallipes $(\mathrm{F}=16.05, \mathrm{df}=1 \& 76, \mathrm{P}<0.01)$. Starved specimens required a lower time than satiated ones $(F=75.98, \mathrm{df}=1 \& 76, P<0.01)$.

\section{Experiment 5}

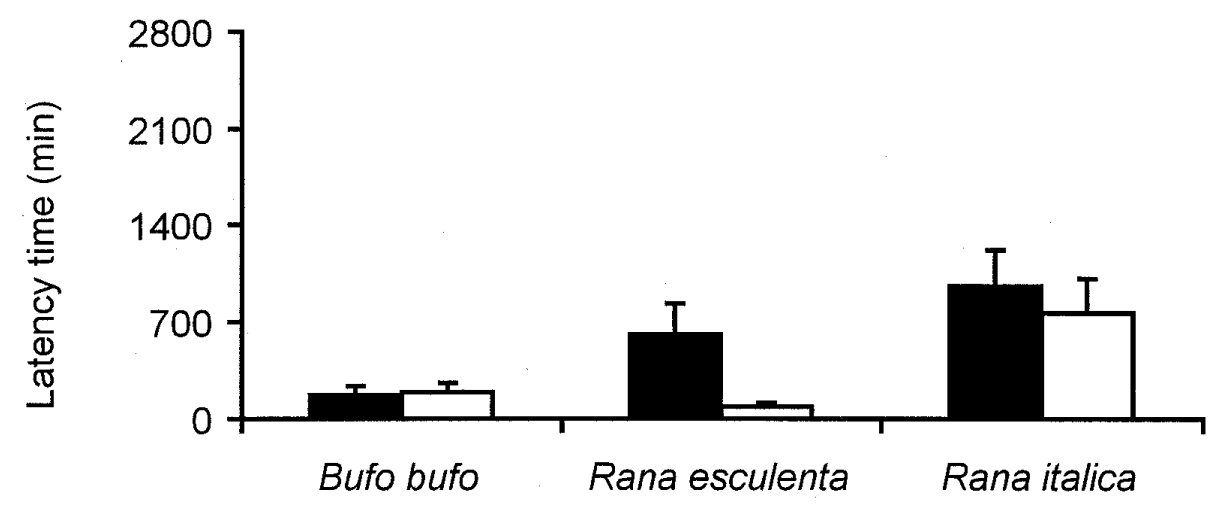

Austropotamobius pallipes

口Procambarus clarkii

\section{Figure 5}

Time spent in capturing one live tadpole by either Bufo bufo or Rana kl. esculenta or R. italica.

\section{Figure 5}

Temps mis pour capturer un têtard vivant soit de Bufo bufo, soit de Rana kl. esculenta, soit de $R$. italica. 
When presented with either one $B$. bufo or $R$. kl. esculenta or $R$. italica live tadpole, latency time was higher for both crayfish $(\mathrm{F}=2.55$, $\mathrm{df}=1 \& 114, \mathrm{P}>0.05)$ when the prey was the latter $(\mathrm{F}=7.98, \mathrm{df}=1 \& 114, \mathrm{P}<0.01)$.

\section{DISCUSSION AND CONCLUSION}

Several authors (see, e.g., REYNOLDS, 1978 ; AXELSSON et al., 1997 ; NYSTRÖM, 1999) reported that crayfish species occurring in Europe, such as $A$. pallipes, Astacus astacus, P. clarkii and Pacifastacus leniusculus, consume amphibian larvae under laboratory conditions. Due to several factors, including the complexity of the natural habitat providing protection to tadpoles (NYSTRÖM, 1999), the results obtained from the artificial and confined laboratory setting do not allow an estimate of the impact of alien crayfish on amphibian populations. Notwithstanding, our experimental protocol provided an understanding of the differential consumption rate of common anuran larvae by native and alien species.

The two crayfish here analysed exhibited a similar motivation and/or ability to capture amphibian prey, without any difference between dead or live tadpoles. This demonstrates that these two species are potential predators of tadpoles. Behavioural observations showed that crayfish mostly adopt a sit-and-wait strategy and this explains why their probability of capturing one prey increases with the number of the available prey. If crayfish were active hunters, several potential prey items swimming in unpredictable directions could have confounded the predator and reduced its ability to follow one of them (BERTRAM, 1978).

The red swamp crayfish appeared faster than the native species in preying on $R$. kl. esculenta tadpoles. Many predators show frequency dependent preference for different prey types : they concentrate on the commonest prey present in the habitat at that moment, "switching " (MURDOCH and OATEN, 1975) from one prey to another on the basis of their differential profitability (KREBS, 1978). Rana kl. esculenta is mostly found in lentic water bodies, in syntopy with the red swamp crayfish in Tuscany. The hypothesis here is that the alien species has formed a " searching image " (DAWKINS, 1971) of this species' tadpoles, as the result of either visual or chemical perceptual changes, allowing a faster detection and an easier capability to catch the species they are familiar with. In the laboratory setting, $P$. clarkii is ready to switch to other species, such as $R$. italica, which they have never encountered in nature. This phenomenon did not happen in the less opportunistic $A$. pallipes.

Larvae of $R$. italica were more difficult prey for both crayfish species, possibly because of their faster swimming performances (FIGIEL and SEMLITSCH, 1991). Amphibian larvae mobility seems to influence the impact by crayfish (HOLOMUZKI, 1989 ; FAUTH, 1990 ; LEFCORT, 1996). In a field experiment using enclosures (NYSTRÖM, 1999), the reduced swimming ability of tadpoles during their metamorphosis (BROWN and TAYLOR, 1995) favoured the heavier predatory pressure exercised on them by Pacifastacus leniusculus. Also, the consumption of amphibian larvae by crayfish may be affected by tadpole palatability. Some amphibians develop granular glands during metamorphosis, which reduce predation due to their unpalatability. The present study showed that both species of crayfish here tested preyed upon larvae and consumed them without any apparent damage for at least two weeks after consumption. In part, this contrasts with a laboratory study by AXELSSON et al. (1997) where Astacus astacus and Pacifastacus leniusculus often failed to consume $B$. bufo larvae. Then, crayfish can be repelled by noxious metamorphic stages, but often consume pre-metamorphic stages (e.g. Cambarus diogenes and Orconectes propinquus vs Rana palustris and Notophtalmus viridescens, FORMANOWICZ and BRODIE, 1982). 
To conclude, both species demonstrated to be skilled predators on anuran larvae, adopting a sit-and-wait behaviour. However, because $P$. clarkii displayed lower latency times in the presence of one of the three amphibians here tested as prey, the hypothesis is not falsified that invasive crayfish are more opportunistic predators and possibly faster in switching to different prey than those species they are displacing. From a conservation perspective, these preliminary results further emphasise the importance of studies centred on the invasion-displacement dichotomy.

\section{ACKNOWLEDGEMENTS}

The work was financed by grants from Regione Toscana and MURST. Thanks are due to Dr Luca Bartolozzi (Museo di Storia Naturale, Università di Firenze). The experimental procedure does not disagree with the Italian laws.

\section{REFERENCES}

AXELSSON E., NYSTRÖM P., SIDENMARK J., BRÖNMARK C., 1997. Crayfish predation on amphibian eggs and larvae. Amphibia-Reptilia, 18, 217-228.

BROWN R.M., TAYLOR D.H., 1995. Compensatory escape mode trade-offs between swimming performance and maneuvering behavior through larval ontogeny of the wood frog, Rana sylvatica. Copeia, 1995, 1-7.

BERTRAM B.C.R., 1978. Living in groups : predators and prey. In : KREBS J.R. and DAVIES N.B. (Eds.), Behavioural Ecology. An evolutionary approach, Blackwell Scientific Publications, Oxford, 64-96.

CEDHAGEN T., NILSSON G. (Eds.), 1991. Grod-och kräldjuren i norden. Katarina Tryck $A B$, Sverige, Fjärde Utgåvan.

CORBETT K. (ed.), 1989. Conservation of European Reptiles and Amphibians. London, Christopher Helm.

DAWKINS M., 1971. Perceptual changes in chicks, another look at the "search image » concept. Anim. Behav., 19, 566-574.

DIAMOND J.M., 1996. A-bomb against amphibians. Nature, 383, 386-387.

DUELLMAN W.E., TRUEB L. 1994. Biology of Amphibians. The Johns Hopkins University Press, Baltimore and London.

FAUTH J.F., 1990. Interactive effects of predators and early larval dynamics of the tree frog Hyla chrysoscelis. Ecology, 71, 1609-1616.

FIGIEL C.R. Jr, SEMLITSCH R.D., 1991. Effects of nonletal injury and habitat complexity on predation in tadpole populations. Can. J. Zool., 69, 830-834.

FISHER R.N., SHAFFER B.H., 1996. The decline of amphibians in California's great central valley. Conserv. Biol., 10, 1387-1397.

FOG K., SCHMEDES A., ROSENØRN DE LASSON D. (Eds.), 1997. Nordens padder og krybdyr. G.E.C. Gad København.

FORMANOWICZ D.R. Jr, BRODIE E.D. Jr, 1982. Relative palatabilities of members of a larval amphibians community. Copeia, 1982, 91-97.

FOSTER J., SLATER F.M., 1995. A global review of crayfish predation with observations on the possible loss of Austropotamobius pallipes in the welsh wye due to crayfish plague. Freshwater Crayfish, 8, 589-613.

GAMRADT S.C., KATS L.B., 1996. Effect of introduced crayfish and mosquito fish on California newts (Taricha torosa). Conserv. Biol., 10, 1155-1162.

GASC J.P., CABELA A., CRNOBRNJA-ISAILOVIC J., DOLMEN D., GROSSENBACHER K., HAFFNER P., LESCURE J., MARTENS H., MARTINEZ RICA J.P., MAURIN H., OLIVEIRA M.E., SOFIANIDOU T.S., VEITHS M., ZUIDERWIJK A. (Eds.), 1997. Atlas of amphibians and reptiles in Europe. Societas Europaea Herpetologica \& Museum National d'Histoire Naturelle (IEGB/SPN), Paris. 
GHERARDI F., BALDACCINI G.N., BARBARESI S., ERCOLINI P., DE LUISE G., MAZZONI D., MORI M., 1999. Case studies of alien crayfish in Europe. The situation in Italy. In : GHERARDI F. and HOLDICH D.M. (Eds.), Crayfish in Europe as alien species. How to make the best of a bad situation ?, Balkema, Rotterdam, 107-128.

GHERARDI F., HOLDICH D.M., 1999. Native and alien crayfish in Europe: an introduction. In : GHERARDI F. and HOLDICH D.M. (Eds.), Crayfish in Europe as alien species. How to make the best of a bad situation ?, Balkema, Rotterdam, 3-9.

GHERARDI F., ACQUISTAPACE P., HAZLETT B.A., WHISSON G., (2002). Behavioural responses to danger odours indigenous and non-indigenous crayfish species : a case study from Western Australia. Marine \& Freshwater Research, in press.

GHERARDI F., BARBARESI S., 2000. Invasive crayfish : activity patterns of Procambarus clarkii in the rice fields of the Lower Guadalquivir (Spain). Archiv für Hydrobiologie, 150, 153-168.

HAZLETT B.A., 2000. Information use by an invading species : do invaders respond more to alarm odors than native species ? Biological Invasions, 2, 289-294.

HOGGER J.B., 1988. Ecology, population biology and behaviour. In : HOLDICH D.M. and LOWERY R.S. (Eds.), Freshwater Crayfish : biology, management and exploitation, Croom Helm, London, 114-144.

HOLDICH D.M., 1996. Austropotamobius pallipes. In : VAN HELSDINGER P.J., WILLEMSE L. and SPEIGHT M.C.D. (Eds.) Background information on invertebrates of the Habitats Directive and the Bern Convention. Part 1. Crustacea, Coleoptera and Lepidoptera. Nature and environment, 79, 1-8.

HOLDICH D.M., REEVE I.D., 1991. Distribution of freshwater crayfish in the British Isles, with particular reference to crayfish plague, alien introductions and water quality. Aquat. Conserv. Mar. Freshw. Ecosys., 1, 139-158.

HOLDICH D.M., REEVE I.D., ROGERS W.D., 1995. Introduction and spread of alien crayfish in British waters-implications for native crayfish populations. Freshwater Crayfish, 8, 99-112.

HOLOMUZKI J.R., 1989. Predation risk and macroalga use by the stream-dwelling salamander Ambystoma texanum. Copeia, 1989, $22-28$.

HUNER J.V., 1977. Introductions of the Louisiana red swamp crayfish, Procambarus clarkii (Girard) : an update. Freshwater Crayfish, 3, 193-202.

HUNER J.V., 1988a. Procambarus in North America and elsewhere. In : HOLDICH D.M. and LOWERY R.S. (Eds.), Freshwater Crayfish: biology, management and exploitation, Croom Helm, London, 39-261.

HUNER J.V., 1988b. Status of crayfish transplantations. Freshwater Crayfish, 7, 29-34.

HUNER J.V., 1995. An overview of the status of crayfish culture. J. Shelff. Res., 14, 539543.

HUNER J.V., AVAULT J.W. Jr, 1979. Introductions of Procambarus spp. Freshwater Crayfish, 4, 191-194.

KREBS J.R., 1978. Optimal foraging : decision rules for predators. In : KREBS J.R. and DAVIES N.B. (Eds.), Behavioural Ecology. An evolutionary approach, Blackwell Scientific Publications, Oxford, 23-63.

LANZA B., 1983. Guide per il riconoscimento delle specie animali delle acque interne italiane. 27. Anfibi, Rettili. (Amphibia, Reptilia). Roma : Consiglio Nazionale delle Ricerche.

LAURENT P.J., 1988. Austropotamobius pallipes and A. torrentium, with observations on their interactions with other species in Europe. In : HOLDICH D.M. and LOWERY R.S. (Eds.), Freshwater Crayfish : biology, management and exploitation, Croom Helm, London, 341-364.

LEFCORT H., 1996. Adaptive, chemically mediated fright response in tadpoles of the southern leopard frog, Rana utricularia. Copeia, 1996, 455-459. 
LINDQVIST O.V., HUNER J.V., 1999. Life history characteristics of crayfish : What makes some of them good colonizers ? In : GHERARDI F. and HOLDICH D.M. (Eds.), Crayfish in Europe as alien species. How to make the best of a bad situation?, Balkema, Rotterdam, 23-30.

MURDOCH W.W., OATEN A., 1975. Predation and population stability. Adv. Ecol. Res., 9, $1-131$.

NYSTRÖM P., 1999. Ecological impact of introduced and native crayfish on freshwater communities: European perspectives. In : GHERARDI F. and HOLDICH D.M. (Eds.), Crayfish in Europe as alien species. How to make the best of a bad situation ?, 63-85.

REYNOLDS J.D., 1978. Crayfish ecology in Ireland. Freshwater Crayfish, 4, 215-220.

SMITH D.C., 1983. Factors controlling tadpole populations of the chorus frog (Pseudacris triseriata) on isle Royale, Michigan. Ecology, 64, 501-510.

WESTMAN K., PURSIAINEN M., WESTMAN P.,1990. Status of the crayfish stocks in Europe. Report of the FAO European inland Fisheries Advisory Commission (EIFAC) Working Party on Crayfish. Kalatutkimuksia-Fiskundersokningar 3. Helsinki.

ZAR J.H., 1984. Biostatistical analysis. Prentice Hall, Englewood Cliffs, New Jersey, USA. 